\title{
Environmental Earth Sciences
}

\section{The hydromorphological state in mountain rivers subject to human impacts: a case study in the North - West of Italy \\ --Manuscript Draft--}

Manuscript Number:

Full Title:

Article Type:

Corresponding Author:

ENGE-D-15-01020R1

The hydromorphological state in mountain rivers subject to human impacts: a case study in the North - West of Italy

Original Manuscript

Claudia Dresti

Istituto per lo Studio degli Ecosistemi Consiglio Nazionale delle Ricerche

Verbania, VB ITALY

\section{Corresponding Author Secondary}

Information:

Corresponding Author's Institution:

Istituto per lo Studio degli Ecosistemi Consiglio Nazionale delle Ricerche

Corresponding Author's Secondary Institution:

First Author:

Claudia Dresti

First Author Secondary Information:

Order of Authors:

Claudia Dresti

Gianfranco Becciu

Helmi Saidi

Marzia Ciampittiello

Order of Authors Secondary Information:

Funding Information:

\begin{tabular}{|c|c|}
\hline Abstract: & $\begin{array}{l}\text { The aim of this paper is the evaluation of the hydromorphological conditions of } \\
\text { mountain rivers subject to extensive human activities. The hydromorphological state of } \\
\text { a river depends on a high number of natural and anthropogenic characteristics, such } \\
\text { as the presence of weirs, dams, or any other human infrastructure close to the } \\
\text { riverbanks. The research focused on the mountain streams in Lake Maggiore } \\
\text { catchment, located in the Italian Alps. The analyses were carried out using the method } \\
\text { CARAVAGGIO (Core Assessment of River hAbitat VAlue and hydro-morpholoGlcal } \\
\text { cOndition), which complies with the EC Water Framework Directive. An intensive } \\
\text { campaign of field surveys was conducted and a great amount of data was collected to } \\
\text { obtain specific synthesis indexes. In particular, the Habitat Quality Assessment (HQA) } \\
\text { and the Habitat Modification Score (HMS) were used to determine the diversification of } \\
\text { natural characteristics and the level of hydromorphological alteration in the study area. } \\
\text { Furthermore, a Lentic-lotic River Descriptor (LRD) was used in support of the } \\
\text { information obtained by HQA and HMS. This research shows that the worst } \\
\text { hydromorphological conditions can be found in rivers characterised by a high level of } \\
\text { human constructions and hydropower plants. } \\
\text { Finally, regression analyses were implemented to search a relationship between HQA, } \\
\text { HMS and some morphological parameters. LRD was correlated to some hydraulic } \\
\text { parameters. The results of this research are characterised by a high stochasticity. }\end{array}$ \\
\hline Response to Reviewers: & $\begin{array}{l}\text { We would like to use this opportunity to sincerely thank the Reviewer for the detailed } \\
\text { comments. } \\
\text { We will take all these comments into account in the revised version of the paper. } \\
\text { Please find a detailed response to each questions/comments point by point below. } \\
\text { 1- In the "Methods" section, where HQA, HMS and LRD indices are introduced, a more } \\
\text { detailed description of these indices is needed. The parameters which effect on these } \\
\text { indices are briefly mentioned but how they effect the decision is not clear. In addition, }\end{array}$ \\
\hline
\end{tabular}


the procedure for determining or measuring these indices has not been explained in the paper.

The procedure for determining the indexes was described in detail in pages 5-6-7, the new part is written in blue and includes the formulas from 1 to 6 . Furthermore, we added the complete procedure as supplementary material for the paper (Online Resource 1).

We also added some reference in which it is possible to find a description of the indices: Raven et al. (1998) and CNR IRSA et al. (2010).

2- The regression analyses of the indices and some morphological and hydraulic parameters of the river showed a poor correlation. Is there a similar research in the literature which investigate these relations? In the case of the answer "Yes", what is the result of the previous researches? Does the current research confirm the previous researches or not?

It is the first time that such research has been carried out with method CARAVAGGIO. A previous study with the method River Habitat Survey has been carried out in the Polish Carpathians and it is described in Bucala and Wiejaczka (2015). This study compares with linear regression both HQA and HMS with the number of buildings and the length of reinforcement. In the study, the Authors do not consider the number of riffle-pool sequences and the percentage of area with anthropic structure.

The results of our study were similar to the ones of this study. In particular, the index HMS showed a clear relationship with the length of reinforcement, while the index HQA seemed very poorly correlated with both the length of reinforcement and the number of buildings.

In our paper, we added this comment and the reference at page 15, in blue.

3- The quality of the figures, specifically figure 5 , is not at the standard level for the journal and should be replaced by the better ones.

We tried to improve the quality of all the figures, especially figure 5 , with respect to the maximum number of figures required by the paper.

4- There are some grammar mistakes that should be corrected by a native english speaker.

The paper was corrected by a native English speaker and the grammar mistakes were corrected.

References

Raven PJ, Holmes TH, Dawson FH, Fox PJA, Everard M, Fozzard IR, Rouen KJ (1998). River Habitat Quality: the physical character of rivers and streams in the UK and Isle of Man. Environmental Agency.

CNR IRSA, CNR ISE, ARPA Piemonte, Regione Sardegna (2010) Guideline and field protocols for deriving hydro-morphological and habitat information. Deliverable Pd3. Project INHABIT - LIFE 08 ENV/IT/000413.

Bucala A, Wiejaczka L (2015) Evaluation of the hydromorphological state of mountain streams under the influence of contemporary human activity (Polish Carpathians). Environ Earth Sci 73: 3451-3463. DOI: 10.1007/s12665-014-3629-3.

Best Regards,

Claudia Dresti 


\section{Cover Letter}

Dear Editor,

On behalf of my co-authors, I am submitting the revised enclosed manuscript entitled "The hydromorphological state in mountain rivers subject to human impacts: a case study in the North West of Italy" for possible publication in Environmental Earth Sciences. I attest to the fact that all the authors have read and approved the paper and it has not been published previously nor is it being considered by any other peer-reviewed journal.

In this manuscript, we evaluate the hydromorphological conditions of mountain rivers subject to extensive human activities. The analyses were carried out using the method CARAVAGGIO (Core Assessment of River hAbitat VAlue and hydro-morpholoGIcal cOndition), which complies with the EC Water Framework Directive. Some analyses were carried out to search a relationship between the synthetics indexes calculated with the CARAVAGGIO procedure and some morphological and hydraulic parameters.

The results of this analysis will be useful for the understanding of the effects of human impacts on the hydromorphology and the ecology of mountain rivers.

Best Regards,

Claudia Dresti 


\section{Response to reviewers}

We would like to use this opportunity to sincerely thank the Reviewer for the detailed comments.

We will take all these comments into account in the revised version of the paper.

Please find a detailed response to each questions/comments point by point below.

1- In the "Methods" section, where HQA, HMS and LRD indices are introduced, a more detailed description of these indices is needed. The parameters which effect on these indices are briefly mentioned but how they effect the decision is not clear. In addition, the procedure for determining or measuring these indices has not been explained in the paper.

The procedure for determining the indexes was described in detail in pages 5-6-7, the new part is written in blue and includes the formulas from 1 to 6 . Furthermore, we added the complete procedure as supplementary material for the paper (Online Resource 1).

We also added some reference in which it is possible to find a description of the indices: Raven et al. (1998) and CNR IRSA et al. (2010).

2- The regression analyses of the indices and some morphological and hydraulic parameters of the river showed a poor correlation. Is there a similar research in the literature which investigate these relations? In the case of the answer "Yes", what is the result of the previous researches? Does the current research confirm the previous researches or not?

It is the first time that such research has been carried out with method CARAVAGGIO. A previous study with the method River Habitat Survey has been carried out in the Polish Carpathians and it is described in Bucala and Wiejaczka (2015). This study compares with linear regression both HQA and HMS with the number of buildings and the length of reinforcement. In the study, the Authors do not consider the number of riffle-pool sequences and the percentage of area with anthropic structure. The results of our study were similar to the ones of this study. In particular, the index HMS showed a clear relationship with the length of reinforcement, while the index HQA seemed very poorly correlated with both the length of reinforcement and the number of buildings.

In our paper, we added this comment and the reference at page 15 , in blue.

3-The quality of the figures, specifically figure 5, is not at the standard level for the journal and should be replaced by the better ones.

We tried to improve the quality of all the figures, especially figure 5, with respect to the maximum number of figures required by the paper. 
4- There are some grammar mistakes that should be corrected by a native english speaker.

The paper was corrected by a native English speaker and the grammar mistakes were corrected.

References

Raven PJ, Holmes TH, Dawson FH, Fox PJA, Everard M, Fozzard IR, Rouen KJ (1998). River Habitat Quality: the physical character of rivers and streams in the UK and Isle of Man. Environmental Agency.

CNR IRSA, CNR ISE, ARPA Piemonte, Regione Sardegna (2010) Guideline and field protocols for deriving hydro-morphological and habitat information. Deliverable Pd3. Project INHABIT - LIFE $08 \mathrm{ENV} / \mathrm{IT} / 000413$.

Bucala A, Wiejaczka L (2015) Evaluation of the hydromorphological state of mountain streams under the influence of contemporary human activity (Polish Carpathians). Environ Earth Sci 73: 3451-3463. DOI: $10.1007 / \mathrm{s} 12665-014-3629-3$.

Best Regards,

Claudia Dresti 
Full Title: The hydromorphological state in mountain rivers subject to human impacts:

a case study in the North - West of Italy

Authors: Claudia Dresti ${ }^{\mathrm{a}}$, Gianfranco Becciu ${ }^{\mathrm{b}}$, Helmi Saidi $^{\mathrm{a}}$, Marzia Ciampittiello $^{\mathrm{a}}$

${ }^{a}$ National Research Council - Institute of Ecosystem Study, Largo Tonolli 50, 28922 Verbania Pallanza (Italy).

${ }^{b}$ Milan Polytechnic - Piazza Leonardo da Vinci 32, 20133, Milano (Italy).

Corresponding author: Claudia Dresti, c.dresti@ise.cnr.it. Largo Tonolli 50, 28922, Verbania Pallanza, Italy, +390323518363 .

\section{Acknowledgements}

The data presented in this study are part of a CNR-ISE scientific collaboration project between the National Research Council - Institute of Ecosystem Study and the Province of Verbano - Cusio Ossola (Italy), aimed at study and research on water resources, carried out from 2009 to 2014. 


\begin{abstract}
The aim of this paper is the evaluation of the hydromorphological conditions of mountain rivers subject to extensive human activities. The hydromorphological state of a river depends on a high number of natural and anthropogenic characteristics, such as the presence of weirs, dams, or any other human infrastructure close to the riverbanks. The research focused on the mountain streams in Lake Maggiore catchment, located in the Italian Alps. The analyses were carried out using the method CARAVAGGIO (Core Assessment of River hAbitat VAlue and hydro-morpholoGIcal cOndition), which complies with the EC Water Framework Directive. An intensive campaign of field surveys was conducted and a great amount of data was collected to obtain specific synthesis indexes. In particular, the Habitat Quality Assessment (HQA) and the Habitat Modification Score (HMS) were used to determine the diversification of natural characteristics and the level of hydromorphological alteration in the study area. Furthermore, a Lentic-lotic River Descriptor (LRD) was used in support of the information obtained by HQA and HMS. This research shows that the worst hydromorphological conditions can be found in rivers characterised by a high level of human constructions and hydropower plants.

Finally, regression analyses were implemented to search a relationship between HQA, HMS and some morphological parameters. LRD was correlated to some hydraulic parameters. The results of this research are characterised by a high stochasticity.
\end{abstract}

Keywords: hydromorphological quality, human impacts, CARAVAGGIO method, mountain rivers, Water Framework Directive. 


\section{Introduction}

Nowadays, mountain rivers are one of the ecosystems that are more affected by human activities around the world (Sala et al. 2000; Gleick 2003; Wohl 2005; Sundermann et al. 2011). Contemporary human influence on streams and rivers threatens the sustainability of 'ecosystems services', i.e. all the services provided by ecosystems (Millennium Ecosystem Assessment 2005). In mountain areas, extensive changes in the channel habitat of rivers and streams, as well as in their nearest environment, are evident (Bucala and Wiejaczka 2015). In particular, hydromorphological impacts can affect stream channels, riparian areas and floodplains either directly, as a result of activities undertaken within the stream channel, or indirectly, from activities within the watershed (Wohl 2006; Elosegi and Sabater 2013). As an example, straightening, channelisation, damming or disconnection from the floodplains are the main activities altering the hydrology and the morphology of most rivers (Reckhow et al. 2005; Smith et al. 2007). Significant changes in the natural environment of river catchments result also from an increase in the number and density of buildings and other human infrastructures, such as roads (Forman and Alexander 1998; Trombulak and Frissel 2000).

In the Alpine region, mountain rivers have modified their channel morphology in response to both natural and human-induced pressures, over the last decades (Comiti 2011). Nowadays, most of the Alpine rivers are dammed (Truffer et al. 2001). Dams are able to capture high water flows and store them for later use: this can result in lowered flood peaks, changes in timing, frequency and duration of high and low flows, and in an alteration of the natural rates at which rivers rise and fall during runoff events (Richter and Thomas 2007). River regulation modifies hydrological, hydromorphological and biological variables and its effects are difficult to predict (Jansson et al. 2000). In this context, it is clear that various factors determine the health of a river ecosystem (Norris and Thoms 1999), such as water quality, river flow and physical structure of the channel and the riparian zone (Acreman and Dunbar 2004). Among these factors, hydromorphological characteristics have an important role, since they have a strong influence on river ecology (Vaughan et al. 2009). In particular, the habitat quality of rivers is considered a reflection of their hydromorphological state: in 
general, the higher the number and diversity of natural features, the better are the conditions of a river

habitat. However, anthropogenic infrastructures modify the habitat of a river (Environment Agency 2003). The evaluation of the hydromorphological state of rivers is one of the requirements contained in the Water Framework Directive (WFD) (European Commission 2000). It requires member states to achieve 'Good Status' in both surface and ground waters. 'Good Status' is the combination of 'Good Chemical Status' and 'Good Ecological Status', which is based on four elements for rivers: macroinvertebrates, macrophytes, fish and phytobenthos. Furthermore, it includes supporting elements affecting the biological status, such as water depth and channel forms. In this context, it is fundamental to evaluate the physical habitat contribution to biodiversity conservation, and, in particular, the hydromorphological quality on the river (Newson and Large 2006).

The aim of this research is the evaluation of the hydromorphological state of some mountain streams located in the Italian Alps, in Piedmont Region, in the Province of Verbano - Cusio - Ossola. In addition, statistical analyses were performed in order to assess the relationship between human influence and mountain rivers habitat quality. The evaluation of the hydromorphological state was based on method CARAVAGGIO (Core Assessment of River hAbitat VAlue and hydromorpholoGIcal cOndition) (Buffagni et al. 2005, 2013).

\section{Methods}

In recent decades, numerous hydromorphological assessment methods have been developed in different countries (Belletti et al. 2015). This research is based on the method CARAVAGGIO, which is compliant with the Water Framework Directive (WFD) (European Commission 2000). This method is based on the structure of the River Habitat Survey (Raven et al. 1997, 1998). The analysis of the hydromorphological state of the rivers in the Province of Verbano - Cusio - Ossola has been performed by the Institute of Ecosystem Study since 2009 (Dresti et al. 2011). The data presented in this paper were collected before autumn 2013. 
The method CARAVAGGIO allows operators to collect a great amount of information, useful in the

description of river habitats, which are considered related to the hydromorphological conditions of the river. Each application of the method consists in two different stages: i) a field survey, during which the operator collects many hydromorphological and hydrological characteristics of the stream; ii) the calculation of quality indexes with the CARAVAGGIO procedure.

In the first stage, data collection is performed on a selected $500 \mathrm{~m}$ segment along the longitudinal axis of the river: this segment is then divided in ten sections (spot-checks) and in each section basic morphological channel features are registered. In particular, the type of flow, the type of material in the riverbed, the channel and the bank modifications, the type of vegetation and the land use. Furthermore, a synthetic description of the entire site (sweep-up) is required and includes some morphological forms and alterations such as the shape of the valley, the presence and number of riffles and pools, bars and sedimentation/erosion areas.

The data registered during the field survey are then elaborated with the CARAVAGGIO procedure. Four synthesis indexes are obtained, three of which have been considered in this research: a) HQA (Habitat Quality Assessment), which allows to evaluate the river habitat diversification and quality, linked to the global quality of the site; b) HMS (Habitat Modification Score), which quantifies the morphological alteration of the site; c) LRD (Lentic-lotic River Descriptor), which characterises the site in terms of lentic-lotic features.

The HQA score is evaluated as the total of all the component scores in these categories: flow types, channel substrates, channel features, bank features, bank vegetation structure, point bars, in-stream channel vegetation, land use within $50 \mathrm{~m}$, trees and associated features, special features such as debris dams, flush, bog. These features are registered both at spot-check and sweep-up level and the scores are summed up to obtain the value of HQA. As an example, considering the category flow type, each predominant flow type scores 1 ; if it occurs in 2-3 spot-checks, it scores 2 ; if it occurs at 4 or more spot-checks, it scores 3 . If only one type occurs at all spot-checks, the scores will be 3 . Dry channels score 0 . 
As regards the HMS index, its score for a site is the total of all the component scores in these main

categories: modifications at spot-check, modification present but not registered at spot-check, scores for features in site as a whole. As an example, considering the category Modifications at spot-check, the feature reinforcement to banks scores 2 , the feature reinforcement to bed scores 2 , the presence of a culvert scores 8 , the presence of resectioned bank of bed scores 1 .

As regards LRD index, being:

$\mathrm{Ch}_{\mathrm{i}}$ : main channel (I) or secondary channel (II)

$\mathrm{a} / \mathrm{n}$ : artificial or natural

$\mathrm{x}$ : number of the spot-check

ww: width of the water for every single channel

$\mathrm{T}_{\mathrm{ww}}$ : total width of the water

The total LRD is obtained as:

$$
L R D=L R D_{a}+L R D_{n}
$$

Where $L R D_{a}$ represents the part of LRD due to artificial features of the channel and $L R D_{n}$ represents the part of LRD due to natural features.

It is possible to define the sum of the scores, due respectively to the flow type $(\mathrm{F})$, the channel substratum (S), the maximum depth of the water (D), and the vegetation in the channel (V):

$$
M H_{a / n, \mathrm{CH} i}=F_{a / n, \mathrm{CH} i}+S_{a / n, \mathrm{CHi}}+D_{a / n, \mathrm{CHi}}+V_{a / n, \mathrm{CH} i}
$$

As an example, considering the Flow type category, a dry or not perceptible flow scores 8, while a lotic flow scores -2 .

For every spot-check it is possible to evaluate the values of $\mathrm{LRD}_{\mathrm{n}}$ and $\mathrm{LRD}_{\mathrm{a}}$ :

$$
L R D_{n}=\frac{\left(M H_{n, C H I}\right)_{x} \cdot w w_{C H I_{x}}+\left(M H_{n, C H I I}\right)_{x} \cdot w w_{C H I_{x}}}{T_{w w, x}}
$$


For the whole site:

$$
\begin{gathered}
L R D_{n}=\sum_{x=1}^{10} L R D_{n, x}+S W C_{n, C H I}+S W C_{n, C H I I}+S W S_{n} \\
L R D_{a}=\sum_{x=1}^{10} L R D_{a, x}+S W C_{a, \text { CHI }}+S W C_{a, \text { CHII }}+S W S_{a}
\end{gathered}
$$

The complete procedure used to evaluate the three indexes is described in Online Resource 1.

The procedure used to evaluate HQA and HMS indexes is the same used in River Habitat Survey method and is also described in detail in Raven et al. (1998). The procedure for LRD index is also described in CNR IRSA et al. (2010).

In order to evaluate the hydromorphological quality, HQA and HMS can be expressed in terms of Ecological Quality Ratio (EQR) (European Commission 2000; CNR IRSA et al. 2010), shown in Eqn. (7) and (8):

$$
E Q R_{H Q A}=\frac{H Q A-11}{54-11}
$$

in which 54 is the median value for HQA in the Alpine region and 11 is the minimum value (CNR IRSA et al. 2010).

$$
E Q R_{H M S}=\frac{100-H M S}{100}
$$

in which 100 is the maximum value possible for HMS.

A Global Hydromorphological Index (GHI) can be evaluated, as shown in Eqn. (9):

$$
G H I=\frac{E Q R_{H M S}+E Q R_{H Q A}}{2}
$$


It is possible to define 5 classes for each index, as shown in Table 1. Since the Water Framework Directive states that the 'Good Ecological Status' should be reached, only three classes were considered for GHI (High, Good and Not Sufficient).

Table 1: Quality classes for each index.

LRD ranges between the values -75 (lotic conditions, typical of mountain streams) and +90 (lentic conditions, which in a mountain stream can be found i.e. upstream from a dam). A detailed description of this index can be found in CNR IRSA et al. (2010).

\section{The study area}

The study area is located in the North - West of Italy, in Piedmont Region, in the Province of VCO (Fig. 1). In particular, it includes river Toce and its main affluents: rivers Devero, Diveria, Bogna, Ovesca, Anza, Isorno and Melezzo Occidentale. Furthermore, other streams in the Province were considered, namely Melezzo Orientale, San Bernardino, San Giovanni and Cannobino.

The territory is in the Alpine region and the Toce catchment is a typical glacial basin, with steep hillslopes bounding a narrow valley. The total drainage area is of about $1534 \mathrm{~km}^{2}$ and its elevation ranges between $193 \mathrm{~m}$ a.s.l. at the outlet section to $4615 \mathrm{~m}$ a.s.l. at the Monte Rosa top. The average elevation is of $1641 \mathrm{~m}$. The local climate is typically Alpine, with higher amount of rainfall in autumn and spring and lower ones in winter. The mean annual precipitation is about $1700 \mathrm{~mm}$, and snow covers the highest altitudes for most of the year (Mancini et al. 1998, 2000; Montaldo et al. 2004).

As regards the land cover, $90-95 \%$ of the total area of the basin is constituted by steep hillslopes, mostly covered by trees on thin soil layers above bedrock. In general, $70 \%$ of the land cover is formed by forest areas, $9 \%$ by bare rocks, $7 \%$ by agricultural uses, $6 \%$ by natural grassland, $4 \%$ by urban areas, $3 \%$ by water bodies, and $1 \%$ by glaciers and perpetual snow (EC 1992).

In river Toce catchment, 14 major reservoirs can be found, with a total effective storage capacity of about $151 \cdot 10^{6} \mathrm{~m}^{3}$. 
As regards river San Bernardino, its drainage basin is $130.84 \mathrm{~km}^{2}$. The elevations range from 193 to

$2301 \mathrm{~m}$ a.s.l. with a mean value of $1228 \mathrm{~m}$ a.s.l. (obtained from the hypsographic curve). The minimum elevation corresponds to the mean water level of Lake Maggiore (193.87 $\mathrm{m}$ a.s.l. for the period 1952-2013). The main characteristic of this catchment is that more than $70 \%$ of the territory is above $1000 \mathrm{~m}$ a.s.1.; about $80 \%$ of its territory is included in the Valgrande National Park and consequently it is almost inhabited and densely forested. The only anthropogenic modification of the drainage network is a dam on the left branch of the stream, which was built at the end of the $19^{\text {th }}$ century to store water for a paper mill and hydroelectric purposes. Since then the use and management of the dam has not changed much, although the mill closed in 1985. This stream has thus been described as having a nivo-pluvial regime (Ciampittiello 1999). The average annual rainfall for this catchment is $2254 \mathrm{~mm}$.

The surface area of the San Giovanni drainage basin, located to the east of the San Bernardino, is 60.7 $\mathrm{km}^{2}$. The elevations range from 193 to $2156 \mathrm{~m}$ a.s.l. with a mean value of $914 \mathrm{~m}$ a.s.1. Only $40 \%$ of the drainage basin is above $1000 \mathrm{~m}$. a.s.l. This drainage basin is more densely populated than that of San Bernardino. In addition, several anthropogenic modifications have affected its drainage network since the 1940s-50s, such as water diversions, dams of various types and sizes for hydropower production. Two more small dams are under construction. River San Giovanni is characterised by a pluvial regime and the average annual rainfall is $1860 \mathrm{~mm}$ (Ciampittiello 1999).

As regards river Cannobino, the catchment area is $110.4 \mathrm{~km}^{2}$. The elevations range from 193 to 2193 $\mathrm{m}$ a.s.l. with a mean value of $1057 \mathrm{~m}$ a.s.l. This stream has a nivo-pluvial regime and the average annual rainfall for this catchment is $2155 \mathrm{~mm}$. Cannobino is the only stream in the Province of Verbano-Cusio-Ossola without anthropogenic modifications.

It is evident that reservoirs represent the greatest human impact in the research area and, for this reason, the method CARAVAGGIO was applied in 39 rivers segments (Fig. 1), placed mostly in correspondence to, or immediately downstream or upstream from reservoirs, in order to evaluate the changes in the hydromorphological state of the river due to the presence of dams. In Fig. 2 the 
CARAVAGGIO surveys sites are shown, with the land use. The names of the survey sites can be found in Fig. 3 and 4, reading them from the left to the right, from 1 to 39.

\section{Results}

\section{The indexes HQA and HMS}

The HQA index values indicate the diversity of the hydromorphological features, in a river segment. For the rivers considered in this research, the HQA values range from 26 to 63 , with values of EQR $\mathrm{HQA}$ respectively of 0.35 and 1.21 . According to the classification by CNR IRSA et al. (2010), 1 among 39 sites is in poor quality conditions, while 14 among 39 sites are in high quality conditions, which means that the naturalness and diversification of habitats is very good. Most of the sites (16 among 39) are in good conditions, while the remaining 8 are characterised by moderate diversification of the habitats.

As regards the HMS index, it reflects the degree of anthropisation in the channel and river banks. For the research area, it ranges from 0 (site without anthropic structures) to 77 of the site Fondovalle, where a very big reservoir is present. The minimum and maximum values of EQR $\mathrm{H}_{\mathrm{HS}}$ are respectively 0.23 (for the most altered site, cfr. the evaluation of $\mathrm{EQR}_{\mathrm{HMS}}$ in the previous paragraph), and 1 (for the least altered site). In particular, according to the classification by CNR IRSA et al. (2010), 1 site is characterised by very modified hydromorphological habitats, 6 among 39 show poor conditions, due to a high degree of anthropogenic modification, 14 among 39 present a moderate quality and 7 among 39 are in good quality conditions, which means that the degree of anthropisation is quite low. 11 sites show a very high quality, due to almost absent human impacts.

The results are presented in Fig. 3. The names of the sites of each river are written from the source to the outlet section of the streams reading from the left to the right.

The results in terms of GHI are reported in Fig. 4. The line GHI=0.63 and GHI=0.85 represent the limit respectively between not sufficient and good quality, and between good quality and high quality. 
From Fig. 4, it is possible to notice that most of the sites have a good global hydromorphological

quality, while just four sites are not in 'Good status'. Among these four sites (river Ovesca-Rovesca; river Devero - Osso; river Alto Toce - Fondovalle; river Melezzo Occidentale - Masera), two are placed in correspondence of big reservoirs, while the other two are placed in urban areas. As highlighted above, the site Fondovalle shows the highest HMS value of the entire sample, and the lowest GHI value.

In general, it is possible to notice that for river basins where the main human impacts are due to an increasing urbanization from the upper to the lower part of the catchment, i.e. river Melezzo Occidentale, the HMS values increase from the source to the outlet section (EQR $\mathrm{HMS}_{\mathrm{S}}$ decreases), while HQA index decreases. For the other streams, the higher the human impacts, the higher the HMS value: for example, for river Ovesca, at Rovesca site HMS is very high, but several kilometres downstream the quality has resulted very high, due to a particularly natural area.

The sites characterised by high GHI values are mostly placed in barely accessible areas (river Ovesca - Rivera; river Bogna - Pianezza; river Melezzo Occidentale - Druogno and a site placed upstream a natural freefall; three site in river Isorno catchment, in an uninhabited valley) or in the upper part of the catchments (river San Bernardino - Tuborg; river San Giovanni - upstream from Scareno; river San Giovanni - upstream and downstream from Ramello).

The values of EQR $\mathrm{HQA}_{\text {and }}$ and $\mathrm{EQR}_{\mathrm{HMS}}$ were compared, using linear regression, with the number of riffle-pool sequences, which are an important morphological structure for fish and macroinvertebrates (cfr. as an example Roussel and Bardonnet 1997), with the length of the channel reinforcement, with the percentage of urbanised area around the considered segment (in an area of $50000 \mathrm{~m}^{2}$ ). The results are reported in Fig. 5.

In Fig. 5, case (a), it is possible to notice the relationship between the indexes EQR $\mathrm{HMS}_{\mathrm{H}}$ and $\mathrm{EQR}_{\mathrm{HQA}}$ and the number of riffle-pool sequences. This relationship is not significant (dotted lines) and the very low value of $\mathrm{R}^{2}$ indicates that both $\mathrm{EQR} \mathrm{RQA}_{\mathrm{HQA}}$ and $\mathrm{EQR} \mathrm{R}_{\mathrm{HM}}$ are very weakly correlated to this hydromorphological feature. This result is quite unexpected for the index HQA: even if in the streams 
of the Alpine region the number of riffle-pool sequences is often quite low due to the morphology of

the valleys (CNR IRSA 2007), in general the higher the number of riffle-pool sequences, the greater the diversification of the habitats. The weak correlation between EQR $\mathrm{HQA}_{\text {and }}$ and the number of poolriffle sequences suggests that in the CARAVAGGIO method other local characteristics may have a higher weight in the evaluation of the diversification of the habitats.

In Fig. 5, case (b), the relationship between the indexes $\mathrm{EQR}_{\mathrm{HMS}}$ and $\mathrm{EQR}_{\mathrm{HQA}}$ and the percentage of urbanised area, in $50000 \mathrm{~m}^{2}$ around the analysed river segment, is shown. Even in this case, the value of $\mathrm{R}^{2}$ is quite low, indicating a high degree of unexplained variance in these results.

The only clear relationship is visible in Fig. 5, case (c), where it is evident the correlation between the index EQR $\mathrm{HMS}_{\mathrm{S}}$ and the length of reinforcement (continuous line): the highest values of HMS index have been registered in the areas with extensive channel banks reinforcement. The corresponding values of HQA index reflect a lower diversification of the habitats. This result is in agreement with the results obtained by Bucala and Wiejaczka (2015) in their analysis of the hydromorphological state in Polish Carpathians.

\section{The index LRD}

Buffagni et al. $(2004,2009)$ highlight the importance of including the lentic-lotic character in the assessment of the ecological quality of a river. In fact, the importance of hydraulic conditions in influencing invertebrate taxa has been demonstrated by many authors (Chutter 1969; Extence et al. 1999; Dolédec et al. 2007). The index LRD is aimed at describing the site in terms of lentic-lotic features. It can range from -75 for very lotic sites, to +90 for very lentic sites.

In Fig. 6 the results for the research area are shown.

The index LRD ranges from the value -65 of the river Ovesca - Rivera, indicating very lotic conditions, to the value 5 of river San Giovanni - downstream from Ramello, indicating lentic conditions. It is possible to notice that the site Rivera is a completely natural site, with very high 
values of GHI and very low value of LRD, the most common situation in natural Alpine streams. On

the other hand, it is possible to observe that the site downstream from Ramello on river San Giovanni is placed in a very natural context (high value of GHI), but it is just downstream from a water intake structure, which results in a lower amount of flow, causing lentic conditions.

The values of LRD were compared with the river flow per unit of catchment area, measured during CARAVAGGIO application with the current meter, and with the velocity in section in the considered segment. In Fig. 7 the results are shown.

From Fig. 7 it is possible to notice that LRD seems weakly correlated to the river flow and very weakly correlated to the current velocity. These results are quite unexpected, since the river flow has a clear strong influence on the lentic or lotic nature of a stream.

\section{Discussion and conclusions}

The analysis of the hydromorphological state of the rivers in the Province of Verbano - Cusio Ossola was very useful in highlighting some critical situations in terms of hydromorphological quality and diversification of the habitat in the territory. The method CARAVAGGIO allows operators to collect a great amount of information, regarding both the morphology and the hydrology of each site. These data, if combined with specific information regarding the human impacts in the basins (such as the land use and the placement of reservoirs and water withdrawals), are important in order to understand the main features influencing the quality of a river, sensu Water Framework Directive (2000). The indexes evaluated with CARAVAGGIO have pointed out the sites where an intervention is necessary to restore the river hydrological and ecological functionality. In particular, HQA resulted higher in more natural areas, where the diversification of the habitats is very good, while HMS resulted higher when human impacts are evident, in particular in sites close to reservoirs or in urban areas. The typical case is river Melezzo Occidentale, in which no hydrological alterations were present (that is to say no reservoirs is present), and the indexes highlighted a decreasing of the quality of the habitats and an increasing of the hydromorphological alterations from the upper to the lower 
part of the basin. In general, the territory of the Province of Verbano - Cusio - Ossola resulted in

good and high hydromorphological conditions in most of its sites, and this can be explained by the presence of many natural mountain areas, some of which are barely accessible. Furthermore, the change in land use in the last decades did not significantly change the urbanization of most of the valleys. The main human impact in this mountain area is the presence of major reservoirs for hydropower production. These reservoirs induce a local morphological alteration that in some sites is very important (i.e. river Toce - Fondovalle), but this alteration does not seem to influence river segments placed at a great distance. Water intake structures induce a hydrological alteration that can be significant, however this research shows that until now the hydromorphological quality of most of the analysed sites is good. It has to be noticed that, even if the hydromorphological quality is acceptable according to the Water Framework Directive, analyses on macroinvertebrates should be carried out to quantify the alterations induced by reservoirs on river fauna.

As regards LRD index, the values indicate lotic conditions in most of the sites, which is the expected condition in mountain streams. This could indicate that the water withdrawals do not change significantly the lentic-lotic character of the rivers in the Province and the greatest impacts can be observed downstream from water intake structures, where the river flow decreases and the current velocity is lower.

A deepened analysis of the relationship among the CARAVAGGIO indexes and some natural or artificial characteristics of the sites show a high degree of unexplained variability. In particular, the normalised indexes $\mathrm{EQR}_{\mathrm{HQA}}$ and $\mathrm{EQR} \mathrm{R}_{\mathrm{HMS}}$ were compared, using linear regression, with the number of riffle- pool sequences observed during the field surveys, the percentage of urbanised area in 50000 $\mathrm{m}^{2}$ around the river segment and the length of the channel banks reinforcement. The correlation between the indexes and these features is very weak, except for the index $\mathrm{EQR}_{\mathrm{HMS}}$ with the length of the reinforcement. These results are in part unexpected, since the higher the number of riffle-pool sequences, the higher the diversification of the habitats in general. Furthermore, the percentage of urbanised area around the CARAVAGGIO application does not seem to influence the EQR $\mathrm{HMS}_{\text {index. }}$ 
While it is the first time that such research is carried out with method CARAVAGGIO, previous

studies in the Polish Carpathians by Bucala and Wiejaczka (2015) using the River Habitat Survey method showed similar results. In particular, the index HMS showed a clear relationship with the length of reinforcement, while the index HQA seemed very poorly correlated with both the length of reinforcement and the number of buildings. These results may be clarified considering the complexity of the hydrological and the morphological processes in a river (in part considered in the CARAVAGGIO method), especially at a local scale, which depends on several external factors (e.g. precipitation, river flow, the slope of the riverbed, the slope of the catchment sides, the type of material in the bed and on the sides, etc.). These factors have local effects that can be very different not only from catchment to catchment, but also in different section of the same river. The interactions among these external forces cannot be foreseen a priori.

The same considerations can be carried out for the relationship between LRD index and the main hydraulic parameters (river flow and mean current velocity). LRD represents an improvement compared to the River Habitat Survey and it was introduced to take into account the influence of the lentic-lotic conditions on the ecological quality of a river. However, LRD seems weakly correlated to the mean river flow in the considered segment and not correlated at all with current velocity, which is unexpected. This may be due to the fact that LRD considers the local hydraulic conditions, which are the most important variables for invertebrate taxa, and not the mean condition of the site. Furthermore, the procedure for the index calculation combines both qualitative and quantitative parameters: combined uncertainties on evaluation of each factor can produce an enhanced noise around the mean behaviour. Further analyses of this issue are worthwhile.

To conclude, the evaluation of the hydromorphological state of a river is very complex and should consider many different parameters. The indexes evaluated with the method CARAVAGGIO represent a synthetic assessment useful to identify priority intervention areas, where it is necessary to restore river functionality. However, these indexes are weakly correlated to some important 
parameters, in particular the main hydraulic parameters, and this unexpected result should be analysed 1 in more details in order to understand its causes.

2

3

4

5

6

7

8

9

10

11

12

13

14

15

16

17

18

19

20

21

22

23

24

25

26

27

28

29

30

31

32

33

34

35

36

37

38

39

40

41

42

43

44

45

46

47

48

49

50

51

52

53

54

55

56

57

58

59

60

61

62

63 


\section{References}

Acreman M, Dunbar MJ (2004) Defining environmental river flow requirements - a review. Hydrol Earth Syst Sc 8(5): 861-876.

Belletti B, Rinaldi M, Buijse AD, Gurnell AM, Mosselmann E (2015) A review of assessment methods for river hydromorphology. Environ Earth Sci 73: 2079-2100. doi: 10.1007/s12665-0143558-1.

Bucala A, Wiejaczka L (2015) Evaluation of the hydromorphological state of mountain streams under the influence of contemporary human activity (Polish Carpathians). Environ Earth Sci 73: 3451-3463. DOI: $10.1007 / \mathrm{s} 12665-014-3629-3$.

Buffagni A, Erba S, Armanini D, De Martini D, Somarè S (2004) Aspetti idromorfologici e carattere lentico-lotico dei fiumi mediterranei: River Habitat Survey e descrittore LRD. Quaderni Ist. Ric. Acque 122: 41-63.

Buffagni A, Ciampittiello M, Erba S (2005) Il rilevamento idromorfologico e degli habitat fluviali nel contesto della Direttiva Europea sulle Acque (WFD): principi e schede di applicazione del metodo CARAVAGGIO. Notiziario dei Metodi Analitici Ist. Ric. Acque, Dicembre 2005(2): 32-46.

Buffagni A, Armanini DG, Erba S (2009) Does the lentic-lotic character of rivers affect invertebrate metrics used in the assessment of ecological quality? J Limnol 68(1): 92-105.

Buffagni A, Demartini D, Terranova L (2013) Manuale di applicazione del metodo CARAVAGGIO

- Guida al rilevamento e alla descrizione degli habitat fluviali. Monografie dell'Istituto di Ricerca Sulle Acque del C.N.R., 1/i, 312 pp.: Roma.

Ciampittiello M (1999) I livelli del Lago Maggiore: una grande risorsa da gestire, un problema da affrontare. Alberti Editore: Verbania, Italy.

Comiti F (2012) How natural are Alpine mountain rivers? Evidence from the Italian Alps. Earth Surface Processes and Landforms 37: 693-707. doi: 10.1002/esp.2267. 
CNR IRSA, CNR ISE, ARPA Piemonte, Regione Sardegna (2010) Guideline and field protocols for

deriving hydro-morphological and habitat information. Deliverable Pd3. Project INHABIT - LIFE $08 \mathrm{ENV} / \mathrm{IT} / 000413$.

Chutter FM (1969) The distribution of some stream intertebrates in relation to current speed. Int. Rev. Ges. Hydrobiol. 54: 413-422.

CNR IRSA (2007) Macroinvertebrati acquatici e Direttiva 2000/60/EC (WFD). Notiziario dei Metodi Analitici dell’Istituto di Ricerca Sulle Acque. 118 pp: Roma.

Dolédec S, Lamouroux N, Fuchs U, Mérigoux S (2007) Modelling the hydraulic preferences of benthic macroinvertebrates in small European streams. Freshwater biol 52: 145-164.

Dresti C, Ciampittiello M, Saidi H, Proverbio M, Tartari M, Pizzorni F (2011) Analisi idromorfologica di alcuni corsi d'acqua della provincia del VCO in rapporto all'utilizzo umano della risorsa idrica. Report CNR-ISE 07-11, 30 pp.

Elosegi A., Sabater S (2013) Effects of hydromorphological impacts on river ecosystem functioning: a review and suggestions for assessing ecological impacts. Hydrobiologia 712: 129-143. DOI: 10.1007/s10750-012.1226-6.

EC (1992) Corine Land Cover Technical Guide, Part I. European Commission, Directorate-General Environment, Nuclear Safety and Civil Protection: Brussels, 101.

Envinronment Agency (2003) River Habitat Survey Guidance Manual: 2003 version. Envinronment Agency: Bristol.

European Commission and Parliament (2000) Directive 2000/60/EC of 20 December 2000 establishing a framework for community action in the field of water policy. European Parliament and Council: Luxembourg.

Extence CA, Balbi DM, Chadd RP (1999) River flow indexing using benthic macroinvertebrates: a framework or setting hydrological objectives. Regul River 15: 543-574.

Forman RT, Alexander LE (1998) Roads and their major ecological effects. Annual review of Ecology and Systematic 29: 207-231+C2. 
Gleick PH (2003) Global Freshwater Resources: soft-path solutions for the 21st century. Science 302:

1524-1528.

Jansson R, Nilsson C, Dynesius M, Andersson E (2000) Effects of river regulation on river-margin vegetation: a comparison of eight boreal rivers. Ecol Appl 10(1): 203-224. http://dx.doi.org/10.2307/2640996.

Mancini M, Montaldo N, Rosso R (1998) Modellazione distribuita degli eventi di piena in presenza di invasi artificiali nel bacino del fiume Toce. Proc. XXVI Convegno di Idraulica e Costruzioni Idrauliche vol. II, Catania, Italy: 237-248.

Mancini M, Montaldo N, Rosso R (2000) Effetti di laminazione di un sistema di invasi artificiali nel bacino del fiume Toce. L'Acqua 4: 31-42.

Millennium Ecosystem Assessment (2005) Ecosystems and Human Well-Being: Biodiversity Synthesis. World Resources Institute: Washington, DC.

Montaldo N, Mancini M, Rosso R (2004) Flood hydrograph attenuation induced by a reservoir system: analysis with a distributed rainfall- runoff model. Hydrol Process 18: 545-563.

Newson, MD, Large, ARG (2006). 'Natural' rivers, 'hydromorphological quality' and river restoration: a challenging new agenda for applied fluvial geomorphology. Earth Surf Proc Landf 31: $1606-1624$

Norris RH, Thoms MC (1999) What is river health?. Freshwater Biol 41: 197-209. DOI: 10.1046/j.1365-2427.1999.00425.x.

Raven PJ, Fox PJA, Everard M, Holmes NTH, Dawson FD (1997). River Habitat Survey: a new system for classifying rivers according to their habitat quality. In: Boon PJ, Howell DL (Eds). Freshwater Quality: defining the Indefinable? Scottish Natural Heritage, The Stationery Office: Edinburgh, pp. 215-234.

Raven PJ, Holmes TH, Dawson FH, Fox PJA, Everard M, Fozzard IR, Rouen KJ (1998). River Habitat Quality: the physical character of rivers and streams in the UK and Isle of Man. Environmental Agency. 
Reckhow KH, Arhonditsis GB, Kenney MA, Hauser L, Tribo J, Wu C, Elcock KJ, Steinberg LJ, Stow

CA, Mcbride SJ (2005) A predictive approach to nutrient criteria. Environ Sci Technol 39: 29132919.

Richter BD, Thomas GA (2007). Restoring Environmental Flows by Modifying Dam Operations. Ecol Soc 12(1): 12.

Roussel JM, Bardonnet A, 1997. Diel and seasonal patterns of habitat use by fish in a natural salmonid brook: an approach to the functional role of the riffle-pool sequence. Bull. Fr. Peche Piscic. 346: 573588.

Sala OE, Chapin FS, Armesto JJ, Berlow E, Bloomfield J, Dirzo R, et al. (2000) Biodiversity - global biodiversity scenarios for the year 2100. Science 287: 1770-1774.

Smith AJ, Bode RW, Kleppel GS (2007) A nutrient biotic index (NBI) for use with benthic macroinvertebrates communities. Ecol Indic 7: 371-386.

Sundermann A, Antons C, Cron N, Lorenz AW, Hering D, Haase P (2011) Hydromorphological restoration of running waters: effects on benthic invertebrate assemblages. Freshwater Biol 56: 16891702. doi: 10.1111/j.1365-2427.2011.02599.x.

Trombulak SC, Frissell CA (2000) Review of ecological effects of roads on terrestrial and aquatic communities. Conserv Biol 14: 18-30.

Truffer B, Markand J, Bratrich C, Wehrli B (2001) Green electricity from Alpine hydropower plants. Mt Res Dev 21: 19-24.

Vaughan IP, Diamond M, Gurnell AM, Hall KA, Jenkins A, Milner NJ, Naylor LA, Sear DA, Woodward G, Ormerod SJ (2009) Integrating ecology with hydromorphology: a priority for river science management. Aquat Conserv 19: 113-125.

Wohl E (2005) Compromised Rivers: Understanding Historical Human Impacts on Rivers in the Context of Restoration. Ecol Soc 10(2):12.

Wohl E (2006) Human impacts to mountain areas. Geomorphology 79: 217-248. 
Tables

1

2

3

4

5

6

7

8

9

10

11

12

13

14

15

16

17

18

19

20

21

22

23

24

25

26

27

28

29

30

31

32

33

34

35

36

37

38

39

40

41

42

43

44

45

46

47

48

49

50

51

52

53

54

55

56

57

58

59

60

61

62

63

64

65

Table 1: Quality classes for each index.

\begin{tabular}{|c|c|c|c|}
\hline EQR $_{\mathrm{HMS}}$ & $\mathrm{EQR}_{\mathrm{HQA}}$ & GHI & Quality \\
\hline$\geq 0.94$ & $\geq 0.84$ & $\geq 0.85$ & High \\
\hline$\geq 0.82$ & $\geq 0.63$ & $\geq 0.63$ and $<0.85$ & Good \\
\hline$\geq 0.58$ & $\geq 0.42$ & $<0.63$ & Moderate \\
\hline$\geq 0.28$ & $\geq 0.21$ & $<0.63$ & Poor \\
\hline$<0.28$ & $<0.21$ & $<0.63$ & Bad \\
\hline
\end{tabular}




\section{Figure legends}

Fig. 1 The study area. The black squares represent the sites where CARAVAGGIO surveys were carried out

Fig. 2 CARAVAGGIO survey sites and land use in the catchments

Fig. 3 EQR $\mathrm{HQA}_{\mathrm{H}}$ and $\mathrm{EQR}_{\mathrm{HMS}}$ indexes values for the individual sections

Fig. 4 GHI values for the individual sections

Fig. 5 Relationship between $\mathrm{EQR}_{\mathrm{HQA}}, \mathrm{EQR}_{\mathrm{HMS}}$ and the number of riffle-pool sequences (a), the percentage of anthropised area (b) and the length of reinforcement (c). The dotted lines represent a non-significant regression model, while the continuous line represents a significant relationship Fig. 6 LRD index for each individual research site Fig. 7 Relationship between LRD and river flow per unit of catchment area and flow velocity. The dotted lines represent a not significant regression model

\section{Supplementary Material}

Online Resource 1 Procedure for the evaluation of the indexes HMS, HQA and LRD. 


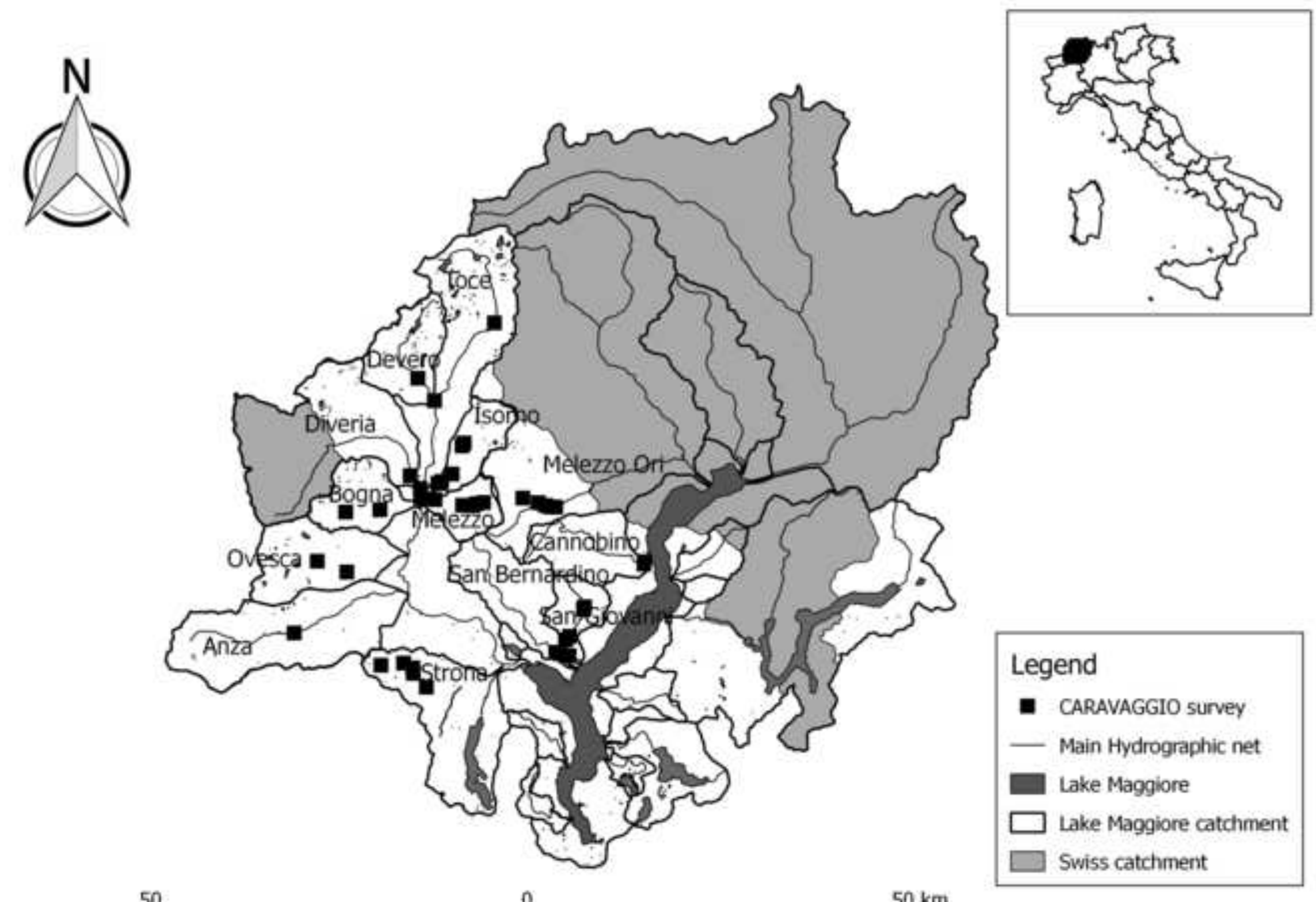




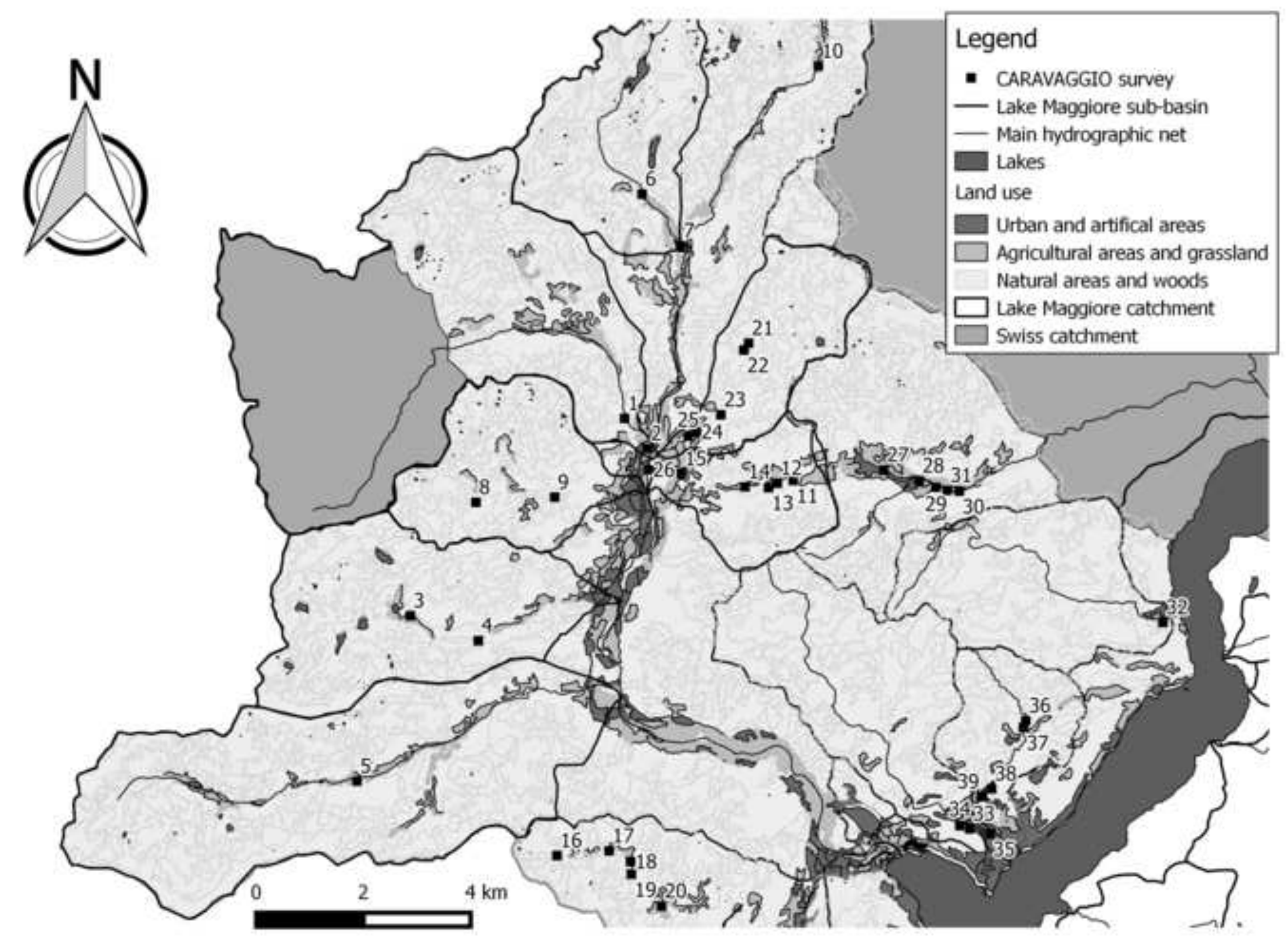




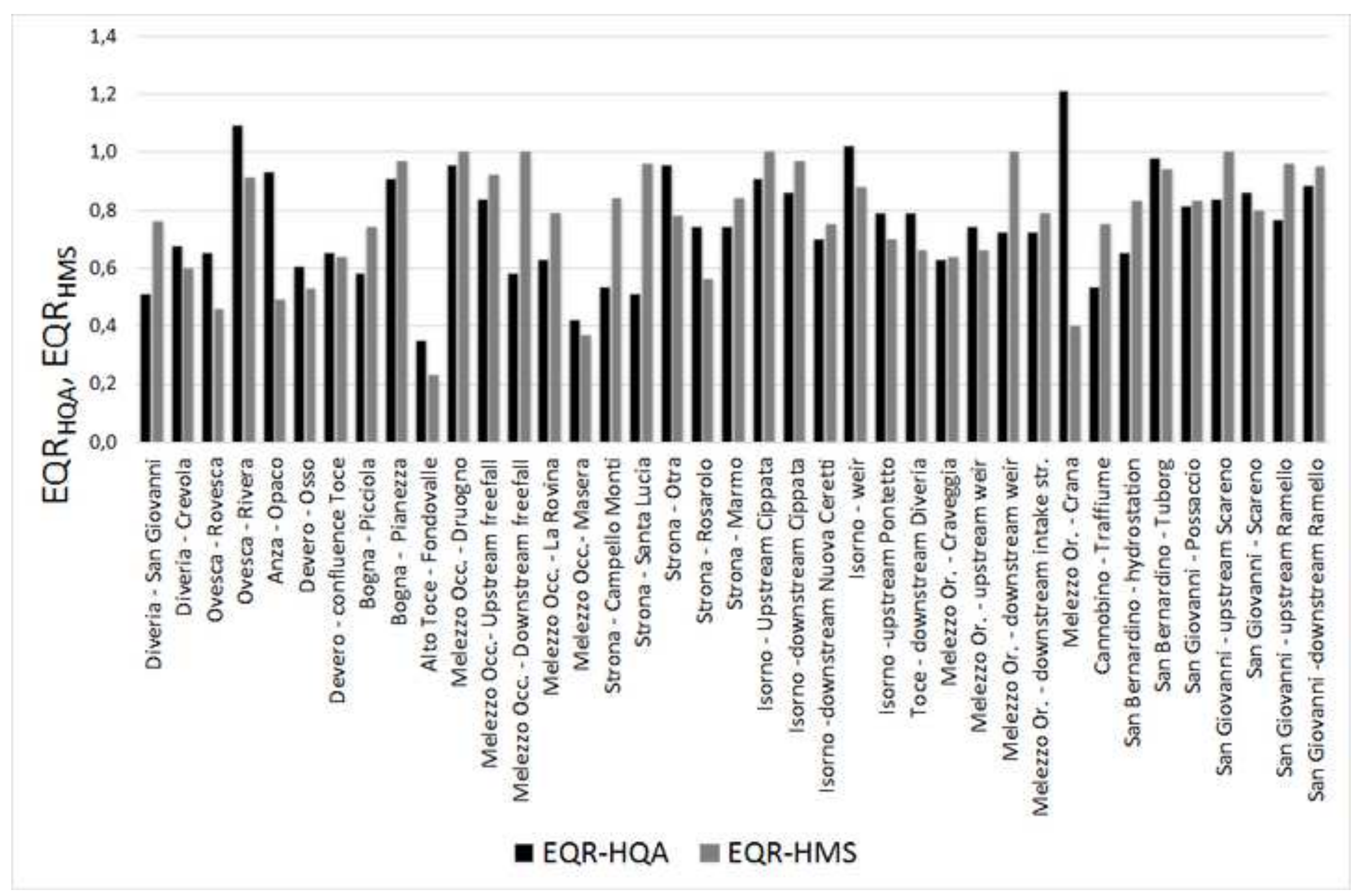




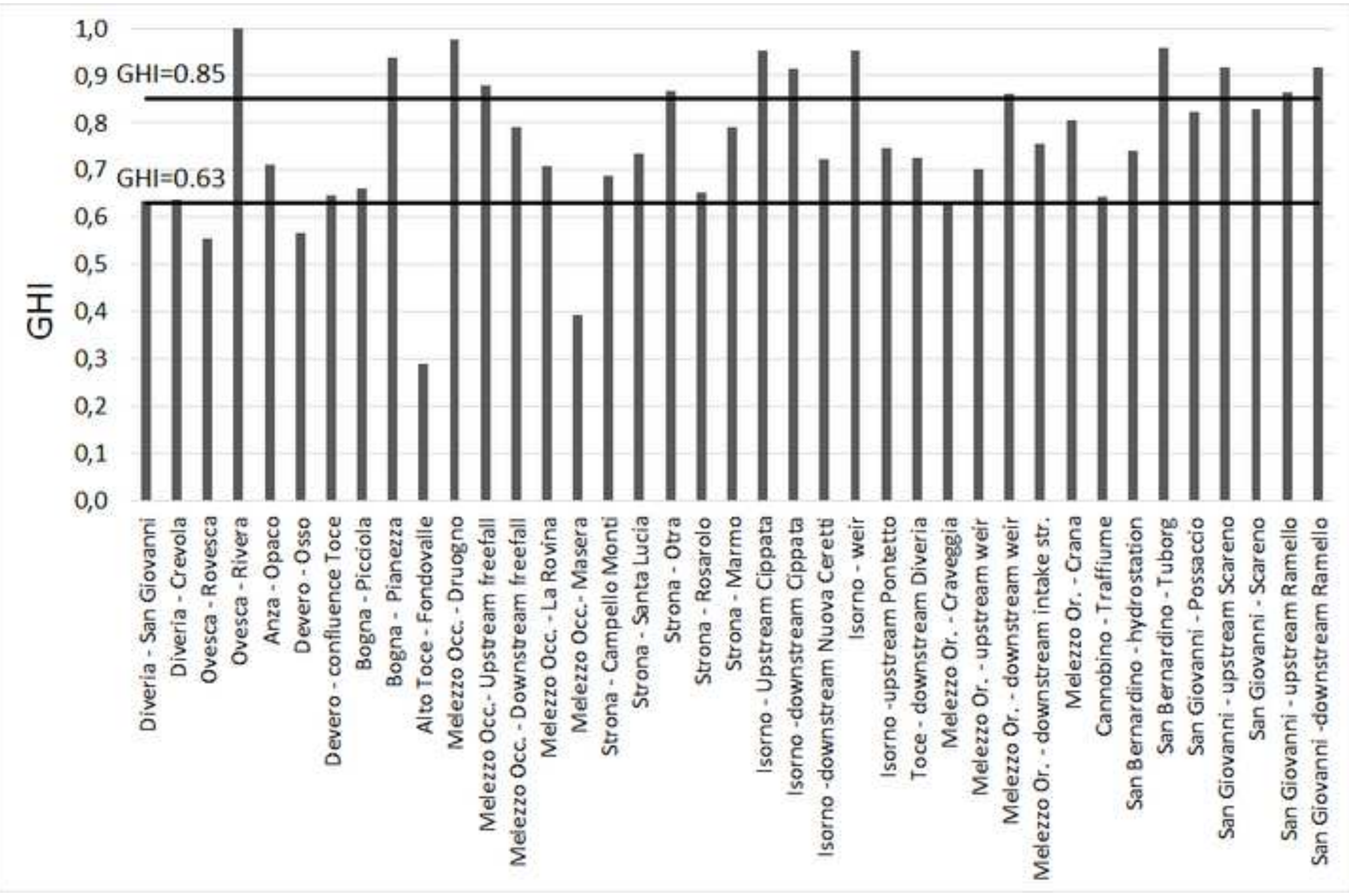



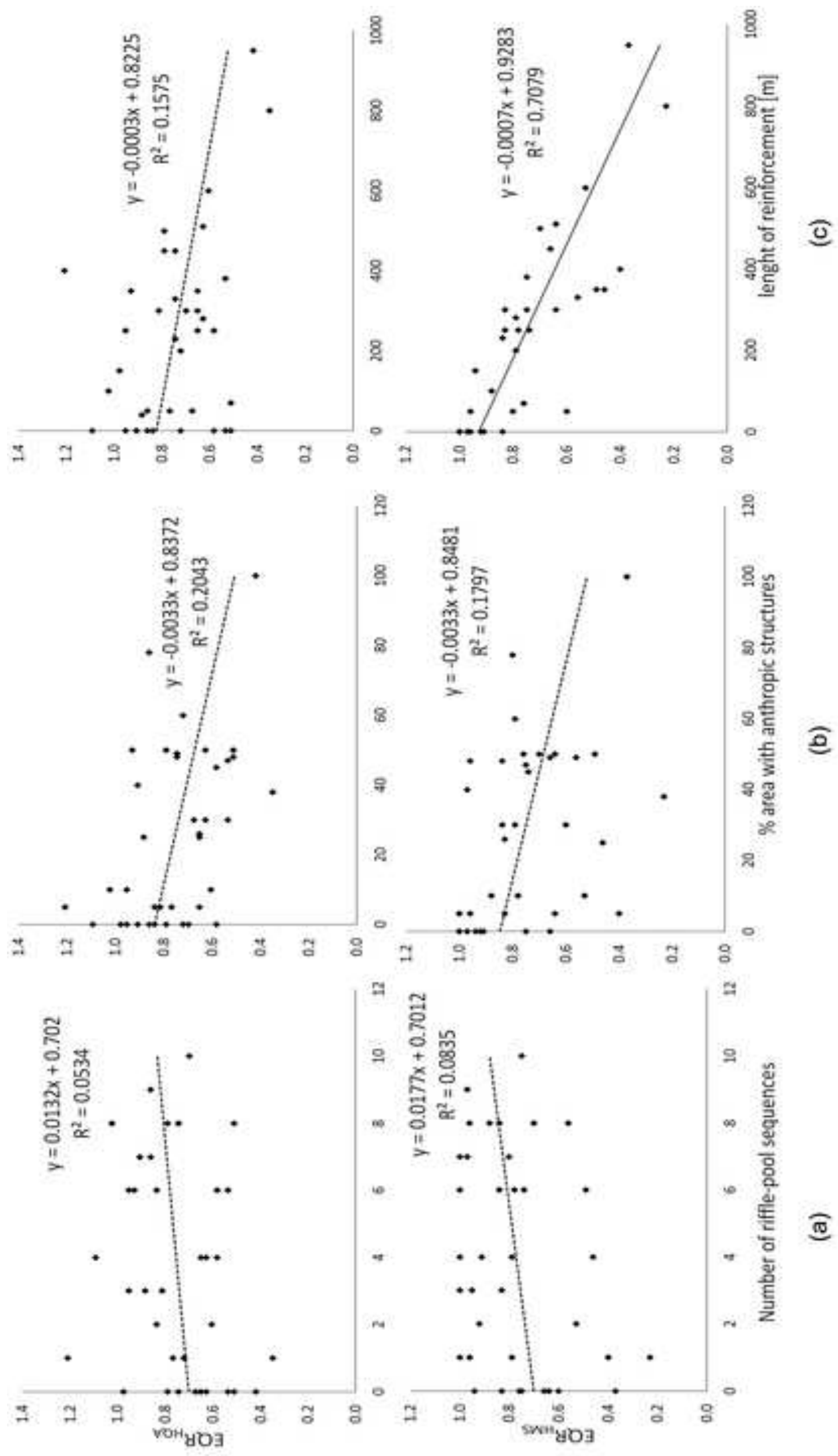


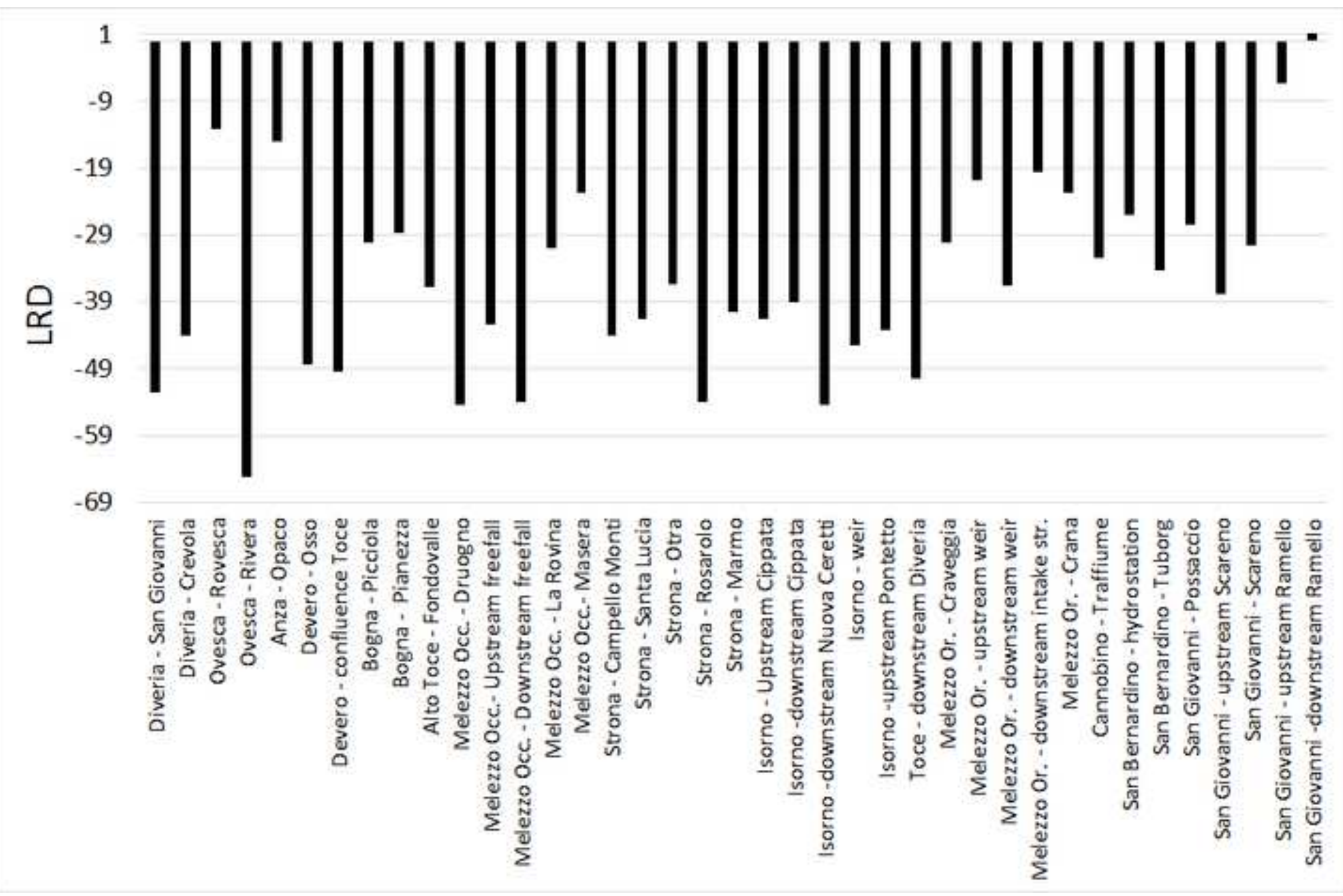



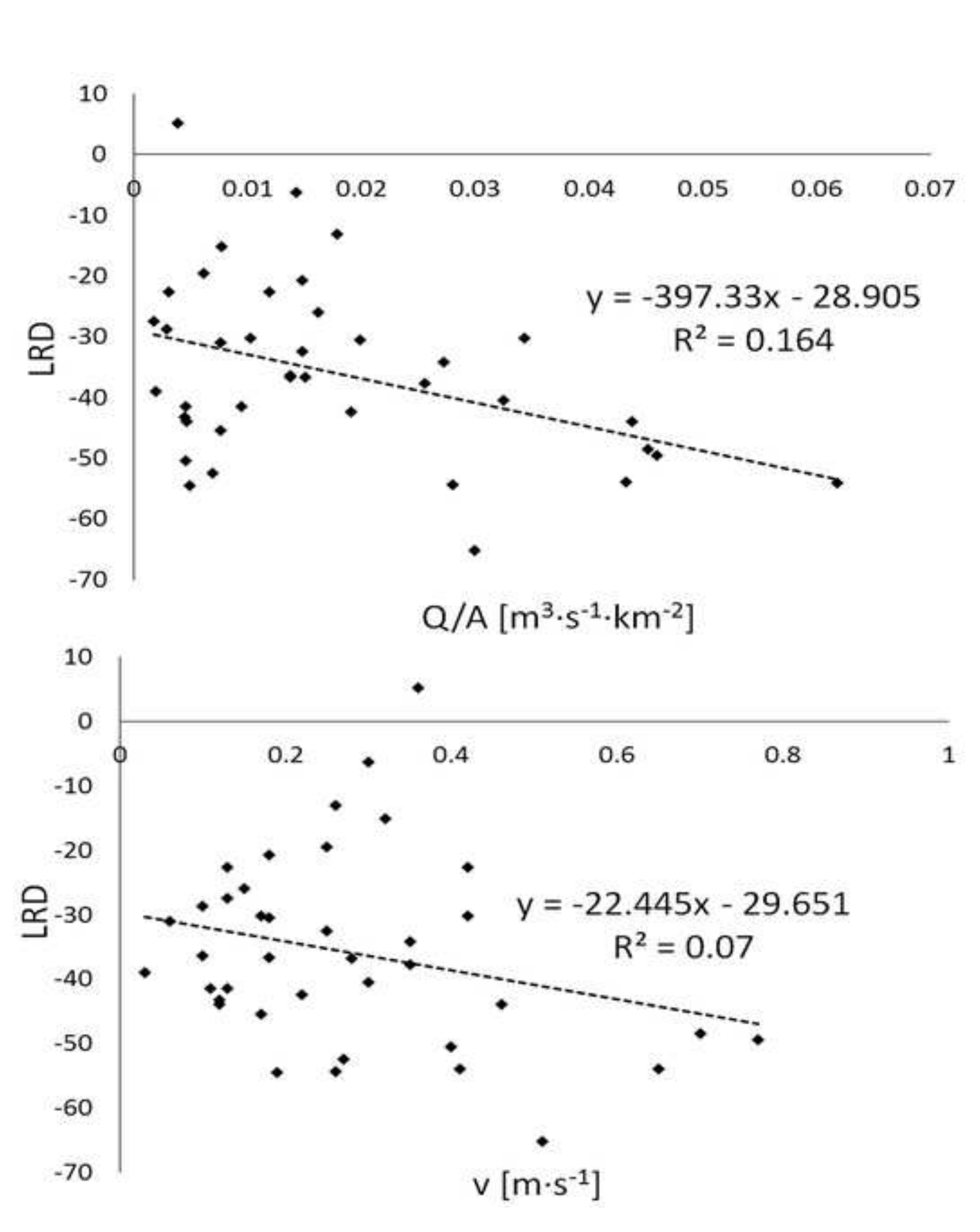

(⿸丆口

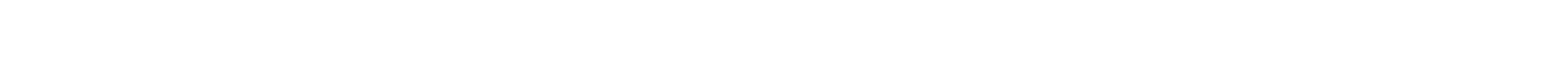



Supplementary Material
\[ \]
Click here to access/download
Suplementary Materia
Online Resource 1.docx

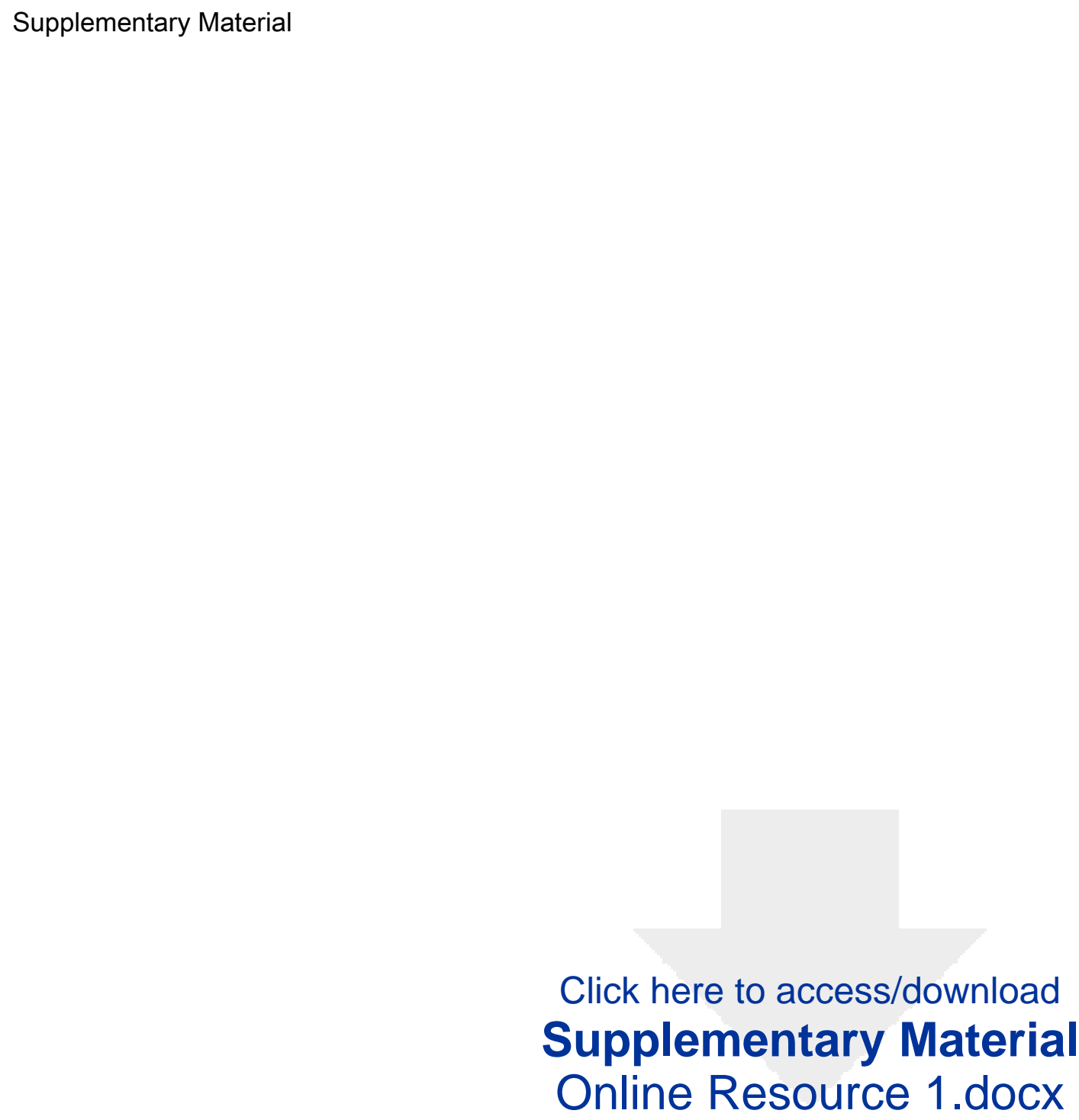
Supplementary Material
\[ \begin{array}{c}\text { Click here to access/download } \\ \text { Onpplementary Material } \\ \text { Online Rource 1.docx }\end{array} \]

\author{
I
}

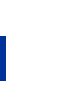

.

-

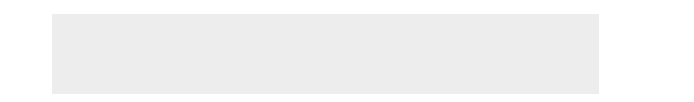

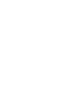

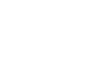

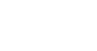

